\title{
NEETin with ICT
}

\author{
Barbas Maria ${ }^{1,2, *}$, Branco Paulo ${ }^{3}$, Loureiro Ana ${ }^{4}$, Matos Pedro ${ }^{5}$ \\ ${ }^{1}$ School of Education of Porto, Portugal \\ ${ }^{2}$ Open University (UAb), Portugal \\ ${ }^{3}$ Department of Educational Technologies, the Polytechnic Institute of Santarem, Higher School of Education, Portugal \\ ${ }^{4}$ Department of Educative Technologies, the Polytechnic Institute of Santarem, Higher School of Education, Portugal \\ ${ }^{5}$ The Polytechnic Institute of Santarem, Higher School of Education, Portugal
}

Copyright $\subset 2017$ by authors, all rights reserved. Authors agree that this article remains permanently open access under the terms of the Creative Commons Attribution License 4.0 International License

\begin{abstract}
Science and Technology Advisory Council (STAC) outlines that $49 \%$ of EU citizens identified "job creation" and 33\% identified "education and skills" as the top priorities for science and technology innovation over the next fifteen years. Both documents justify the needs in Europe for the ICT field especially for the NEET (not in education, employment or training) citizens. On the other hand, Grand Coalition for Digital Jobs (GC4DJ) in Europe identifies: the training and matching digital jobs; certification; innovative learning and teaching; mobility; awareness raising; increasing effectiveness of education; increasing equity and producing positive impact in the economy, as a priority for European countries. NEETin is a project directed to NEET citizens, to be developed by Higher Education Institutions, VET providers and Enterprises in order to help to overcome a social European dimension through lifelong learning. By creating a Joint Vocational Education Training in Digital Competences in a collaboration between VET providers and the Enterprises, widening the access to higher education, in an innovative student-centred learning model to apply in a European level, we aim to contribute to improve the quality of Education. Through this certified JVET, NEET citizens will develop their digital skills and the success of employability of these learners will be enhanced.
\end{abstract}

Keywords ICT, NEET, Digital Employability, Jobs, New Technologies, Digital Competences, Inclusion, Equity, Integration of Refugees

\section{Introduction}

Work-based learning (WBL) is a fundamental aspect of vocational training - it is directly linked to the mission of Vocational Education and Training (VET) to help learners acquire knowledge and skills essential for their working life.

Countries with strong apprenticeship systems report very good results in terms of young people's transition to employment. Learners acquire the skills they need for a first step into the labour market, while employers train their workforce with a view to supplying the knowledge and skills they need to stay competitive. The aim is to create "real life" work environments, establish contacts and /or cooperation with real companies or clients, and develop entrepreneurship skills. In this model, schools or training centres have the main responsibility for creating real life working environments. VET schools are equipped with school workshops, labs, kitchens and restaurants, or cooperate with business and industry to use their facilities. The mandatory share of learning in these working environments varies, depending on the type of VET. Work in practice firms or junior firms and real-life project assignments are frequently used and often form mandatory parts of curricula. Bearing this in mind we designed our innovative proposal, of a joint vocational training program about digital competences, offering a Make Space Lab with a FabLab work environment to help students embedding in the real life work environment. By having the CIONET network and two enterprises students will be able to complement their training with internships, in order to transfer their learning and developed competences into the enterprise reality. These students will be highly skilled professionals in the field of digital literacy.

Also, the digital economy is growing at seven times the rate of the rest of the economy. The European economy, it is estimated that the value added of this sector is around $€ 600$ billion (4.8\% of total GDP) and investments in ICT are responsible for $50 \%$ of all Europe's productivity growth. Particularly important is that this sector due to their technological nature, promotes the $\mathrm{R} \& \mathrm{D}$ investment. Organisation for Economic Co-operation and Development (OECD) data, for example, shows that in Korea and Finland was hit investment in R \& D in ICT higher to $1.5 \%$ of the respective GDPs. Additionally, in the EU, this sector accounts for $25 \%$ of all business investments in R \& D.

In Portugal, the ICT sector is one of the most developed, assuming a national relevance higher than in most European 
countries. Revenues to the GDP in the Portuguese ICT sector are around $4.5 \%$, while the EU15 average is approximately $2.7 \%$. As it would be expected this sector has also in Portugal, a significant weight in terms of R \& D. ICT represents $30 \%$ of business investment and $26 \%$ of academic R \& D investment. In addition, Portugal has communication infrastructure of the most advanced in Europe, the level of fixed networks and next-generation mobile. In large part, these advances are due to public investment in R \& D in ICT very significant and sustained over the past decades which correspond to about $12 \%$ of all public investment in R \& D.

In the last five years, the Portuguese Foundation for Science and Technology (FCT) invested, about 44 million euros in the formation of highly qualified human resources, 4,000 doctoral and post-doctoral; 30 million in R \& D projects and about EUR 28 million in institutional funding, spread over 23 research centres.

As said, this project will allow the use of the critical mass created by this investment by the Portuguese government to put it into tangible outputs.

\section{Materials and Methods}

In order to achieve the proposed objectives we have defined a methodology based in 5 main stages.

In each stage we will use different sub methods and develop several activities in order to achieve the main milestones of the project, to provide skills and integrate NEET citizens.

a) Understanding social and work dimensions

- In order to understand the NEET background and current situation we will do a Literature review of the State of the Art concerning NEET population and will identify best practices and models in teaching and learning concerning the target group

b) Drawing solutions for a social dimension

- To create a new method of teaching and learning to suite the NEET needs

- Interaction with the stakeholders in order to identify the EU ICT needs and understand the type of qualification and competences and the possibilities of jobs and careers - questionnaires will be developed, applied and analysed, in a qualitative and quantitative research.

- A map of the labour market needs in EU ICT matching the partner enterprises needs will be developed to prepare a strategy for the NEET as a workforce

- Bearing in mind the previous results, partners will Design the curriculum of the JVET pilot course in Digital Competences along with a user friendly student-centred learning model (Make Space Lab)

- Design of communication strategies

- Quality plan developed with the QuTE method in a compared study of the EQAVET criteria.

- Reports of these studies will be produced c) Testing solutions and verifying a model

- Focus group of NEET citizens to test the Joint VET course (JVET) (composed by 30 attendees, 10 from each country VET provider (PT, IT, LT))

- Afterwards the whole group will validate the JVET through an Intensive Study Program (ISP)

- Adjustments to JVET for a final version (LEVEL 5 $\mathrm{EQF})$ to be fully accredited in each participating country

- The learners will develop and enhance their digital competences in a new learning and training environment, helping them to a better integration in the labour market through diverse institutions/enterprises or through the development of their own professional project

- The JVET contemplates an internship in order to learners be able to enhance, demonstrate and apply their new ICT skills

- Through the practice in the Make Space Lab and in the internships the learners and future work force will contact with real life work contexts and interact with enterprises (through the CIONET

- network), having the possibility of a real chance of work

d) Building a network

- Higher Education Institutions (HEI) and VET providers have the opportunity to build a real network of collaboration with enterprises and therefore making a correspondence between education and work contexts (filling in the gap of qualified ICT workers)

- The close contact with VET providers, Ministries of Education and EQAVET and the quality provided by the JVET, will allow the certification and accreditation in this network prepared to change other European NEET citizens

e) Sharing Knowledge

- Dissemination will be carried on a local/national with open days (one in each country) for the presentation of the project evolution and results at the time. These open days will coincide with the transnational meetings between partners

On a European/international level dissemination will be carried through diverse kinds of communication and products/events target to the NEET citizens, scientific community, enterprises, European CIONET stakeholders, Ministries of Education and EQAVET in order to bring into discussion and promote the JVET as a solution to the NEET reality.

\section{Results}

The results expected are almost all explained in the Intellectual outputs, Multiplier Events and in Training and Teaching Activities. We expect both tangible (the ones that will be the actual products of the activities) and intangible 
(the ones that we don't see as a form of a product but are important achievements that cannot be neglected) results.

During the project we expect to share good practices among partners in order to create an actual development of innovation. The innovative elements, already stated in this document will surround the short cycle higher education course developed and designed specially to the NEET population. By having the input of so many agents and partners (such as HEI, VET providers, Enterprises and NGO's) that have expertise in various fields (like youth, business, higher education and training), we aim to develop the best methodologies to apply in the training of these citizens. And, with that to positively change their lives, both in academic and skills terms, but also in other competences socially and culturally important to their inclusion in the society and later on in the labour market.

In terms of outputs developed and produce that will represent tangible results, there will be:

1. Meeting reports in each transnational meeting (results to aims 1,2 and 7);

2. Several e-books with the syllabus and content for each curricular unit in the course (results to aims 2, 4 and 6);

3. A full report with the methodologies applied to develop the course (with the help of partnership, stakeholders and the students themselves) - (result to aims 1 and 7);

4. A toolbox, as a multiservice (web, mobile app) platform where all the previous content will be available and that later could be disseminated to the partner countries (in order to replicate this course/training - (result to aims 1 and 7);
5. Two Massive Open Online Courses, one as a smaller course about the contents of the short cycle to address NEET from around Europe (that can't do the short cycle in presence) and one addresses to the problematic of employability (how to develop a CV, how to create your own enterprise, how to get the job you want) - (result to aims 3 and 5);

6. A document for the policy makers to alert for the reality of the NEET population (including the refugees' citizens) and what can be done to address this problem in a more effective way - (Result to aim 2).

In terms of intangible results some of them are already underlined in the document but in a systematic way, we aim to increase:

- $\quad$ The knowledge on the subject of NEET (and refugees) population;

- The ICT skills of this inactive citizens;

- The social, work and cultural competences of the NEET (and refugees) population;

- The awareness of this reality in Europe and in the partner countries;

We are therefore confident that these results may last long after the completion of the project and that can promote an upskilling and the employability of these citizens, by using the best methodologies we can, and that can be applied and replicated in other European countries.

Overview of short term results and long term outcome indicators 1

\begin{tabular}{|c|c|c|c|}
\hline Short term results & $\begin{array}{l}\text { Target groups/potential } \\
\text { beneficiaries }\end{array}$ & Quantitative indicators & Qualitative indicators \\
\hline $\begin{array}{l}\text { Development of the curricular units and } \\
\text { their relevance and articulation within the } \\
\text { course; syllabus, bibliography }\end{array}$ & $\begin{array}{l}\text { NEET citizens; HEI and } \\
\text { VET providers; Partnership; } \\
\text { Enterprises. } \\
\end{array}$ & $\begin{array}{l}\text { Number of curricular units } \\
\text { developed: }(20)\end{array}$ & \\
\hline $\begin{array}{l}\text { Development of the methodologies, } \\
\text { general and specific objectives }\end{array}$ & $\begin{array}{l}\text { NEET citizens; HEI and } \\
\text { VET providers; Partnership. }\end{array}$ & & $\begin{array}{l}\text { Methodologies developed for } \\
\text { all curricular units: } 0=\mathrm{No} \text {; } \\
\qquad 1=\text { Yes (1) } \\
\text { General and specific objectives } \\
\text { developed for all curricular } \\
\text { units: } 0=\mathrm{No} ; 1=\text { Yes }(1)\end{array}$ \\
\hline Accreditation & $\begin{array}{l}\text { NEET citizens; HEI and } \\
\text { VET providers; } \\
\text { VET regulator; } \\
\text { Enterprises; Partnership. }\end{array}$ & & $\begin{array}{l}\text { All curricular units credited: } \\
0=\mathrm{No} ; 1=\text { Yes }(1)\end{array}$ \\
\hline $\begin{array}{l}\text { Development of the contents for the } \\
\text { e-modules (learning, teaching and training } \\
\text { materials) }\end{array}$ & $\begin{array}{l}\text { NEET citizens; HEI and } \\
\quad \text { VET providers; } \\
\text { Enterprises; Partnership. }\end{array}$ & $\begin{array}{l}\text { Number of e-modules developed: } \\
\qquad(20)\end{array}$ & \\
\hline $\begin{array}{l}\text { Development of the contents for the } \\
\text { MOOC (learning, teaching and training } \\
\text { materials) }\end{array}$ & $\begin{array}{l}\text { NEET citizens; HEI and } \\
\quad \text { VET providers; } \\
\text { Enterprises; Partnership. }\end{array}$ & Number of MOOC: (3) & \\
\hline $\begin{array}{c}\text { Development of the contents for the } \\
\text { Fab-lab (learning, teaching and training } \\
\text { materials) }\end{array}$ & $\begin{array}{l}\text { NEET citizens; HEI and } \\
\quad \text { VET providers; } \\
\text { Enterprises; Partnership. }\end{array}$ & $\begin{array}{c}\text { Percentage of }(\%) \text { prototypes }+ \\
\text { devices developed in the Fab-Lab: } \\
(30 \%)\end{array}$ & \\
\hline $\begin{array}{l}\text { Development of the contents for the APPs } \\
\text { (learning, teaching and training materials) }\end{array}$ & $\begin{array}{l}\text { NEET citizens; HEI and } \\
\text { VET providers; } \\
\text { Enterprises; Partnership. }\end{array}$ & $\begin{array}{c}\% \text { of contents developed for the } \\
\text { APP: }(30 \%)\end{array}$ & \\
\hline
\end{tabular}


Overview of short term results and long term outcome indicators 1 (continued)

\begin{tabular}{|c|c|c|c|}
\hline Short term results & $\begin{array}{l}\text { Target groups/potential } \\
\text { beneficiaries }\end{array}$ & Quantitative indicators & Qualitative indicators \\
\hline $\begin{array}{l}\text { Development of the contents for the } \\
\text { gamification (learning, teaching and } \\
\text { training materials) }\end{array}$ & $\begin{array}{l}\text { NEET citizens; HEI and } \\
\quad \text { VET providers; } \\
\text { Enterprises; Partnership. }\end{array}$ & $\begin{array}{l}\% \text { of contents developed for the } \\
\text { gamification: }(40 \%)\end{array}$ & \\
\hline $\begin{array}{l}\text { Development of the tools to support the } \\
\text { e-modules }\end{array}$ & $\begin{array}{l}\text { NEET citizens; HEI and } \\
\text { VET providers; Partnership; } \\
\text { Enterprises. } \\
\end{array}$ & $\begin{array}{l}\text { Number of tools developed to } \\
\text { support the e-modules: (1) }\end{array}$ & \\
\hline $\begin{array}{l}\text { Development of the tools to support the } \\
\text { MOOC (WordPress - open source) }\end{array}$ & $\begin{array}{l}\text { NEET citizens; HEI and } \\
\text { VET providers; } \\
\text { Partnership. } \\
\end{array}$ & $\begin{array}{l}\text { Number of tools developed to } \\
\text { support the MOOC: (1) }\end{array}$ & \\
\hline $\begin{array}{l}\text { Development of the tools to support the } \\
\text { Fab-labs (available in the various } \\
\text { countries. ex: IPS has a Fab-lab) }\end{array}$ & $\begin{array}{l}\text { NEET citizens; HEI and } \\
\text { VET providers; } \\
\text { Partnership. }\end{array}$ & $\begin{array}{l}\text { Number of tools developed to } \\
\text { support the Fab-Lab: (5) }\end{array}$ & \\
\hline $\begin{array}{c}\text { Development of the tools to support the } \\
\text { APPs }\end{array}$ & $\begin{array}{l}\text { NEET citizens; HEI and } \\
\text { VET providers; } \\
\text { Partnership. } \\
\end{array}$ & $\begin{array}{l}\text { Number of tools developed to } \\
\text { support the APPs: (1) }\end{array}$ & \\
\hline $\begin{array}{l}\text { Development of the tools to support the } \\
\text { gamification (Sightsee software) }\end{array}$ & $\begin{array}{l}\text { NEET citizens; HEI and } \\
\text { VET providers; } \\
\text { Enterprises } \\
\text { Partnership. }\end{array}$ & $\begin{array}{l}\text { Number of tools developed to } \\
\text { support the gamification: (1) }\end{array}$ & \\
\hline $\begin{array}{c}\text { Development of the pedagogical and } \\
\text { didactical guidelines to guide the teaching } \\
\text { and learning activities that will take place } \\
\text { with the e-modules (OER) }\end{array}$ & $\begin{array}{l}\text { HEI and VET providers; } \\
\text { Stakeholders; Partnership. }\end{array}$ & & $\begin{array}{l}\text { Pedagogical guidelines for the } \\
\text { e-modules: } 0=\text { No; } 1=\text { Yes }(1) \\
\text { Didactical guidelines for the } \\
\text { e-modules: } 0=\text { No; } 1=\text { Yes }(1)\end{array}$ \\
\hline $\begin{array}{c}\text { Development of the pedagogical and } \\
\text { didactical guidelines to guide the teaching } \\
\text { and learning activities that will take place } \\
\text { with the MOOC }\end{array}$ & $\begin{array}{l}\text { HEI and VET providers; } \\
\text { Stakeholders; Partnership. }\end{array}$ & & $\begin{array}{l}\text { Pedagogical guidelines for the } \\
\text { MOOC: } 0=\text { No; } 1=\text { Yes }(1) \\
\text { Didactical guidelines for the } \\
\text { MOOC: } 0=\text { No; } 1=\text { Yes }(1)\end{array}$ \\
\hline $\begin{array}{l}\text { Development of the pedagogical and } \\
\text { didactical guidelines to guide the teaching } \\
\text { and learning activities that will take place } \\
\text { in the Fab-labs }\end{array}$ & $\begin{array}{l}\text { HEI and VET providers; } \\
\text { Stakeholders; Partnership. }\end{array}$ & & $\begin{array}{r}\text { Pedagogical guidelines for the } \\
\text { activities in the Fab-Lab: } 0=\text { No; } \\
1=\text { Yes (1) } \\
\text { Didactical guidelines for the } \\
\text { activities in the Fab-Lab: } 0=\text { No; } \\
1=\text { Yes (1) }\end{array}$ \\
\hline $\begin{array}{c}\text { Development of the pedagogical and } \\
\text { didactical guidelines to guide the teaching } \\
\text { and learning activities that will take place } \\
\text { with the APPs }\end{array}$ & $\begin{array}{l}\text { HEI and VET providers; } \\
\text { Stakeholders; Partnership. }\end{array}$ & & $\begin{array}{r}\text { Pedagogical guidelines for the } \\
\text { activities with the APPs: } 0=\mathrm{No} \text {; } \\
\qquad 1=\text { Yes (1) } \\
\text { Didactical guidelines for the } \\
\text { activities with the APPs: } 0=\mathrm{No} \text {; } \\
1=\text { Yes (1) }\end{array}$ \\
\hline $\begin{array}{l}\text { Development of the pedagogical and } \\
\text { didactical guidelines to guide the teaching } \\
\text { and learning activities that will take place } \\
\text { with the gamification }\end{array}$ & $\begin{array}{l}\text { HEI and VET providers; } \\
\text { Stakeholders; Partnership. }\end{array}$ & & $\begin{array}{l}\text { Pedagogical guidelines for the } \\
\text { activities with the gamification: } \\
0=\text { No; } 1=\text { Yes }(1) \\
\text { Didactical guidelines for the } \\
\text { activities with the gamification } \\
0=\text { No; } 1=\text { Yes }(1)\end{array}$ \\
\hline $\begin{array}{l}\text { Translation of contents done in English } \\
\text { to all partner's languages and also to } \\
\text { French and Spanish for the VET } \\
\text { exploitation package (cf. work package } \\
\text { 10) }\end{array}$ & & $\begin{array}{l}\text { Number of contents translated to } \\
\text { PT: (150) }\end{array}$ & \\
\hline Make Space Lab & $\begin{array}{c}\text { NEET citizens; } \\
\text { HEI and VET providers; } \\
\text { Enterprises; } \\
\text { Partnership. }\end{array}$ & $\begin{array}{l}\% \text { of students integrated in the } \\
\text { Make Space Lab: }(100)\end{array}$ & $\begin{array}{l}\text { Development of a Make Space } \\
\text { Lab in Portugal, Italy and } \\
\text { Lithuania: } 0=\text { No; } 1=\text { Yes (1) }\end{array}$ \\
\hline $\begin{array}{l}\text { Learning, teaching and training materials } \\
\text { - Intensive study program with focus } \\
\text { group }\end{array}$ & $\begin{array}{l}\text { NEET citizens; } \\
\text { HEI and VET providers; } \\
\text { Enterprises; } \\
\text { Partnership. }\end{array}$ & $\begin{array}{c}\text { Number of focus group per } \\
\text { partner: (1) } \\
\text { Number of students interviewed } \\
\text { per partner: (30) } \\
\text { Number of teachers interviewed } \\
\text { per partner: }(5) \\
\text { Number of stakeholders } \\
\text { interviewed per partner: }(5)\end{array}$ & \\
\hline
\end{tabular}


Overview of short term results and long term outcome indicators 1 (continued)

\begin{tabular}{|c|c|c|c|}
\hline Short term results & $\begin{array}{c}\text { Target groups/potential } \\
\text { beneficiaries }\end{array}$ & Quantitative indicators & Qualitative indicators \\
\hline $\begin{array}{l}\text { Learning, teaching and training materials } \\
- \text { study of results }\end{array}$ & $\begin{array}{l}\text { HEI and VET providers; } \\
\text { Partnership. }\end{array}$ & & $\begin{array}{l}\text { WebQDA (content) analysis of } \\
\text { the study: } 0=\text { No; } 1=\text { Yes (1) }\end{array}$ \\
\hline $\begin{array}{l}\text { Learning, teaching and training materials } \\
\qquad- \text { Final Course }\end{array}$ & $\begin{array}{l}\text { NEET citizens; } \\
\text { HEI and VET providers; } \\
\text { Enterprises; } \\
\text { Partnership. }\end{array}$ & $\begin{array}{l}\text { Number of certified courses (1); } \\
\text { Number of certified students (30). }\end{array}$ & $\begin{array}{l}\text { Joint Vocational Training } \\
\text { Program validated and } \\
\text { recognized by the national } \\
\text { Agency in PT: } 0=\text { No; } 1=\text { Yes (1) } \\
\text { Joint Vocational Training } \\
\text { Program validated and } \\
\text { recognized by the national } \\
\text { Agency in IT: } 0=\text { No; } 1=\text { Yes (1) } \\
\text { Joint Vocational Training } \\
\text { Program validated and } \\
\text { recognized by the national } \\
\text { Agency in GR: } 0=\mathrm{No} ; 1=\mathrm{Yes} \\
(1)\end{array}$ \\
\hline
\end{tabular}

Overview of short term results and long term outcome indicators 2

\begin{tabular}{|c|c|c|c|}
\hline Long term outcome & $\begin{array}{c}\text { Target groups/potential } \\
\text { beneficiaries } \\
\end{array}$ & Quantitative indicators & Qualitative indicators \\
\hline $\begin{array}{c}\text { Widen the access to higher } \\
\text { education }\end{array}$ & $\begin{array}{c}\text { NEET citizens; } \\
\text { HEI and VET providers; } \\
\text { Enterprises; } \\
\text { Partnership. }\end{array}$ & $\begin{array}{c}\% \text { of students that access in a } \\
\text { higher education course: }(30 \%) \\
\% \text { of students that will access in a } \\
\text { higher education course and in } \\
\text { the labour market at the same } \\
\text { time }(2 \%)\end{array}$ & \\
\hline Foster employability & $\begin{array}{c}\text { NEET citizens; } \\
\text { Enterprises. }\end{array}$ & $\begin{array}{c}\text { Rate of employability of students } \\
\text { involved: }(62 \%)\end{array}$ & \\
\hline Change policies & $\begin{array}{l}\text { NEET citizens } \\
\text { HEI and VET providers; } \\
\text { Policy makers. }\end{array}$ & & Change Policies in Europe: $0=$ No; $1=$ Yes (1) \\
\hline $\begin{array}{l}\text { Joint master degree for the } \\
\text { policy makers }\end{array}$ & $\begin{array}{c}\text { Policy makers; } \\
\text { HEI and VET providers. }\end{array}$ & & Joint master degree created: $0=\mathrm{No} ; 1=\mathrm{Yes}(1)$ \\
\hline
\end{tabular}

\section{Discussion}

The project dissemination was planned in a clear execution of dissemination results. We included appropriate activities, tools and channels to ensure that results and benefits will be spread effectively not only with all the participants but also to the stakeholders within and after project life-cycle. E.g.: (a) disseminate results in the Open network Platform of the project and at the EU dissemination platform; and (b) use a diversity of discussion opportunities: Memorandum Day of the Grant Collision for NEET for the establishment of an EU_NEET_ICT council for Policy Makers, open days, workshops, information sessions, training courses, target written materials (such as reports, articles, newsletter, press release, brochures...), Audio-visual products (YouTube) social network (FB, RSS), public events and existing networks; (2) for impact, there will be significant leveraging impact (broader policies, wandering social challenges, focus on innovative technology and boosting support for the labour market), (3) to scale up sustainability the project will develop and integrate innovative skills (recognition/validation through smart and business intelligence applications) and promote a (re)use creation of learning materials and new ways to educate
NEET people online; (4) in order to leveraging exploitation the project will insist in influencing future policies (at local, regional, national, European and international levels), in creating positive reputational effects for the participating organizations; increase awareness on e-skills_NEET area of work, develop new partnerships, promote reforms in the research/HEI/Business triangle, influence policies and practices (Network for HEI reforms experts) to promote reform and enhance progress in NEETS' training.

Regarding exploitation, we share the opinion that this project will have a positive impact, with reputational effects for the participating organization team; increase the awareness in ICT_NEET area; develop a new partnership, influence in a local, regional, national, European and international policy; promote reforms and enhance progress and attitudes in NEET, HEI and entrepreneur organizations, by creating new employments, new firms, and new scientific knowledge (through the Joint Vocational Education and Training Course).

We will also use the CIONET network across all Europe to help in the exploitation of the project, possibly by creating internships and/or jobs in other European countries.

The outcomes will be used by the partners and other stakeholders because the course will be validated in each 
country. This will also have positive effects for the participating organizations' team; and increase awareness in digital competence work.

To conclude, and as we presented in the previous topic, we will enhance the certifications payment in what concerns the courses that we are going to develop through accreditation.

The sources of information on these indicators of measures are:

- Document analysis (course plans and assessment rubrics);

- $\quad$ Evaluation (stakeholder satisfaction level with projects quality)

- Course consultation reports.

- Nature and number of new policies adopted.

- Number of research presentations and dissemination course

- $\quad$ External Evaluator Report

\section{Conclusions}

In the entire Go Making Future project we value knowledge and competences; consequently we defend the free access to knowledge and information. So, in order to grant the access to the intellectual outputs and the tangible deliverables, all materials will be available in a public space, such as the project website and other virtual spaces developed by the partners along the project. We'll also create a mobile app "toolbox" with the syllabus, content and methodologies of the courses and workshops developed during the project that we'll be available for free to the community.

In order to have and open access in the contents of the project we'll also develop two MOOC courses for people that can't be enrolled in the short cycle course (since this is a formal course). In this way we extend the access of these contents to other population interested in the project or the contents provided. We intend to promote free and open seminars and conferences where the interested population can freely access the results and the evolution of the project.

Since we are content and information producers resorting on a digital and open source (website, online and mobile platforms) all contents will be available to everyone during and after the completion of the project. MOOC's, e-books and other materials will stay available in Internet (free access), in the case of the MOOC's the students can actually do the course even after the end of the project. The maintenance of the websites and apps developed will be guaranteed by the coordinator of the project. Also, the use of these materials for NEET and refugees' population is guaranteed thanks to the fact of the short cycle course being an actual course of ESE/IPS institution, in that order even after the project the course will remain active to everyone who wants to enrol. Also, by having the toolbox this course could eventually be exploited to other European countries. In a subsequent phase of the project, the good practices can and should continue, as fieldwork, by the partners and stakeholders in their local regions to a wider range of persons trained and employed.

We will share the results in a diversity of ways such as: at the EU dissemination platform, our project website, by developing ideas for future cooperation through the participation in dedicated discussion opportunities (information sessions, workshops, seminars and training courses) and also by making available online the written material (i.e. reports and scientific papers). The results that are more relevant to disseminate will be identified during the process of the project by the partners, after discussing in the meetings. This kind of discussion will be illuminating for partners since it is expected that contextual or cultural differences may require specific approaches in which it will be interesting to focus on. This kind of brainstorming will also be a mean to involve the whole team since all elements will have the opportunity to share their own experiences and to compare it with the others. Synergies with stakeholders will be developed also thanks to their participation in the dissemination events that will be organized. Their opinion will count greatly in order to assess the benefits of the course and its fitting into the needs of the labour market. Being the integration and inclusion of these citizens a big concern for all European countries and governments the stakeholders will surely be interested in participating and in sharing the results among their networks.

Since the course will keep functioning, more and more students will keep having access to it and to be training for the labour market, the methodologies created during the project funding will still be applied.

The MOOCs will be kept online and anyone at any time can have access and study the information provided there. In the case of the papers and of the MOOCs, the resources needed for their maintenance will be residual since, once they are done, all that is needed is that they keep available, and this is assured by the organizations responsible for the journals and for the MOOCs.

As for the course, as long as there will be potential students interested in it, the ESES will keep it functioning. And by being transferred to other countries with similar needs it will be available in there too, because this experience can be replicated in other countries and by other institutions not implicated in this project. This will be made possible thanks to the fact that all the steps of the project will be made known in a free access way so that anyone can know what we have done and re-use it.

The reports that will be sent to policy makers also aim at a long lasting impact because if policy makers are alert and support this kind of activities, these are bound to be further replicated.

\section{REFERENCES}

[1] Barbas, M.,Abreu, Catarina, Branco, Paulo, Gouveia, Valter Pinto, Ricardo (2013). Percurso científico-pedagógico de 
construção da UC de "Artes e Multimédia": sentido de partilha (roteiros de aprendizagem) | ambiente tecnológico (elearning)| foco de inovação (MOOC). https://www.smashwords.com/books/view/287808. ISBN: 9789899826403

[2] Barbas, Maria (2015). Capitulo de Livro "Elearning platform: network, impact in HEI"IGI Global - 'Handbook of Research on Innovations in Information Retrieval, Analysis, and Management'. (pg. 290 a 308).

http://www.igi-global.com/publish/call-for-papers/call-details $/ 1307$

[3] Barbas, M., Branco, P., Dias, I., Casimiro, E.,Ronsivalle, G., Costa, C., Cortoni, I., \& Preisinger-Kleine, R. (2016).Uptake ICT - an erasmus+ project for digital inclusion, to be presented at INTED 2016 in Valencia, Spain.

[4] Raminhos, R., Coutinho, E., Miranda, N., Barbas,M., Branco, P., Gonçalves, T., \& Palma, G. (2016). SMART Mail - A SMART platform for mail management to be presented at ICEIS 2016 in Rome, Italy.

[5] Barbas, M.; Valerio, G.; Rodríguez-Martínez, M.; Herrera-Murillo, D. and Belmonte-Jiménez, A.. (2014) Online Social Networks and Computer Skills of University Students. In: Nunes, M. and McPherson, M. (Eds) Proceedings of the International Conference e-Learning 2014. Multi Conference on Computer Science and Information Systems. (pp: 294-298). ISBN: 978-989-8704-08-5. (Lisbon, Portugal, July 15-19, 2014). [http://files.eric.ed.gov/fulltext/ED557289.pdf

[6] Barbas, M. (2012). Reflection synthesis of a eLearning situated apprenticeship throughout the course unit of Seminar: e-content | E-tutoring | e-platform. Rivista In-formazione, N.10, "Qualità, competenze e valutazione a scuola. Monitoraggio e valorizzazione dei processi di innovazione dei 4 Piani Nazionali del MIUR", Anno V - numero 9 - 2012. Falzea Editore. ISSN 1970-6723[http://www.mediamonitormi nori.it/pdf-informazione/10/intero_10.pdf]

[7] Loureiro, A. \& Barbas,M. (2014). Active Ageing - Enhancing Digital Literacies in Elderly Citizens. In: P. Zaphiris, P. \& Ioannou, A. (Eds.): Learning and Collaboration Technologies. Technology-Rich Environments for Learning and Collaboration, LNCS 8524, pp. 450-459. Springer International Publishing. DOI: 10.1007/978-3-319-07485-6_44
[8] Barbas, Maria; Lopes, Nuno; Menino, Ana; Rita, Almeida; Manuel, Mascarenhas (2013). "Desafios Societales: Empreendedurismo, innovación en la construcción de un MOOC sobre Realidad Aumentada". XVIII Congreso Internacional de Tecnologias para la Educación y el Conocimiento. Facultad de Educación. UNED. ISBN: 978-84-695-7990-9.

[9] Barbas, M. (2013). Plataforma de eLearning "e.raízes_redes": eixos |arquiteturas |contextos. Parceria Científica Portugal-Brasil para produção de uma publicação. eBook luso-brasileiro 2013 (capítulo entregue para publicação emebook)

[10] Barbas, M. (2013). Reflection_synthesis of a eLearning situated apprenticeship throughout the course unit of Seminar: e-content | E-tutoring | e-platform. Rivista In-formazione, N.10, "Qualità, competenze e valutazione a scuola. Monitoraggio e valorizzazione dei processi di innovazione dei 4 Piani Nazionali del MIUR", Falzea Editore (in corso di stampa).

[11] Branco, P., Barbas, M. (2012). Cognitive Effects of the use of Television and Internet. Humanities and Social Sciences Review. International Journal of Arts and Sciences. Vol 1, No. 4. IJAS Conference proceedings. http://www.internationaljournal.org/

[12] Loureiro, A., Messias, I. \& Barbas, M. (2012). Embracing Web 2.0 e 3.0 tools to support lifelong learning - Let learners connect. Procedia - Social and Behavioral Sciences Journal. Proceedings of the 4th WCES 2012. Elsevier. (ISSN: 1877-0428)

[13] Barbas, M. (2006). Expanding knowledge: from classroom into cyberspace. The Official Quarterly Journal of the International Council for Educational Media, 43, 1, 65-73. doi: $10.1080 / 09523980500490885$

[14] Loureiro, A., Costa, C., Oliveira, N. \& Barbas, M. (2011). e-Moderation in Virtual Environments - Enhancing e-Learning Contexts in Higher Education. In Torres, I., Chova, L. \& Martinez, A. (Eds.). ICERI2011 Proceedings CD (pp 3635-3643). International Association of Technology, Education and Development (IATED) (ISBN: 978-84-615-3324-4). 